\title{
Evidence for a $\mathrm{K}_{\mathrm{ATP}}$ Channel in Rough Endoplasmic Reticulum (rerk $\mathrm{ATP}_{\mathrm{A}}$ Channel) of Rat Hepatocytes
}

\author{
Sajjad Salari ${ }^{1,2,3 \odot}$, Maedeh Ghasemi ${ }^{2 \odot}$, Javad Fahanik-Babaei ${ }^{3}$, Reza Saghiri ${ }^{4}$, \\ Remy Sauve ${ }^{5}$, Afsaneh Eliassi ${ }^{1,2 *}$
}

1 Neurophysiology Research Center, Shahid Beheshti University of Medical Sciences, Tehran, Iran, 2 Department of Physiology, Medical School, Shahid Beheshti University of Medical Sciences, Tehran, Iran, 3 Neuroscience Research Center, Shahid Beheshti University of Medical Sciences, Tehran, Iran, 4 Department of Biochemistry, Pasteur Institute of Iran, Tehran, Iran, 5 Department of Molecular and Integrative Physiology and Membrane Protein Research Group, Université de Montréal, Montréal, Québec H3C 3J7, Canada

จ These authors contributed equally to this work.

* af.eliassi@sbmu.ac.ir

\section{Gopenaccess}

Citation: Salari S, Ghasemi M, Fahanik-Babaei J, Saghiri R, Sauve R, Eliassi A (2015) Evidence for a $\mathrm{K}_{\text {ATP }}$ Channel in Rough Endoplasmic Reticulum

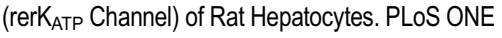
10(5): e0125798. doi:10.1371/journal.pone.0125798

Academic Editor: Agustin Guerrero-Hernandez, Cinvestav-IPN, MEXICO

Received: November 15, 2014

Accepted: March 25, 2015

Published: May 7, 2015

Copyright: @ 2015 Salari et al. This is an open access article distributed under the terms of the Creative Commons Attribution License, which permits unrestricted use, distribution, and reproduction in any medium, provided the original author and source are credited.

Data Availability Statement: All relevant data are within the paper.

Funding: This work was supported by the grant 1202-87/12/12 from the Neuroscience Research Centre of Shahid Beheshti University of Medical Sciences. The funders had no role in study design, data collection and analysis, decision to publish, or preparation of the manuscript.

Competing Interests: The authors have declared that no competing interests exist.

\section{Abstract}

We report in a previous study the presence of a large conductance $\mathrm{K}^{+}$channel in the membrane of rough endoplasmic reticulum (RER) from rat hepatocytes incorporated into lipid bilayers. Channel activity in this case was found to decrease in presence of ATP $100 \mu \mathrm{M}$ on the cytoplasmic side and was totally inhibited at ATP concentrations greater than $0.25 \mathrm{mM}$. Although such features would be compatible with the presence of a $\mathrm{K}_{\text {ATP }}$ channel in the RER, recent data obtained from a brain mitochondrial inner membrane preparation have provided evidence for a Maxi-K channel which could also be blocked by ATP within the mM concentration range. A series of channel incorporation experiments was thus undertaken to determine if the ATP-sensitive channel originally observed in the RER corresponds to $K_{\text {ATP }}$ channel. Our results indicate that the gating and permeation properties of this channel are unaffected by the addition of $800 \mathrm{nM}$ charybdotoxin and $1 \mu \mathrm{M}$ iberiotoxin, but appeared sensitive to $10 \mathrm{mM}$ TEA and $2.5 \mathrm{mM}$ ATP. Furthermore, adding $100 \mu \mathrm{M}$ glibenclamide at positive potentials and $400 \mu \mathrm{M}$ tolbutamide at negative or positive voltages caused a strong inhibition of channel activity. Finally Western blot analyses provided evidence for Kir6.2, SUR1 and/or SUR2B, and SUR2A expression in our RER fractions. It was concluded on the basis of these observations that the channel previously characterized in RER membranes corresponds to $\mathrm{K}_{\mathrm{ATP}}$, suggesting that opening of this channel may enhance $\mathrm{Ca}^{2+}$ releases, alter the dynamics of the $\mathrm{Ca}^{2+}$ transient and prevent accumulation of $\mathrm{Ca}^{2+}$ in the $\mathrm{ER}$ during $\mathrm{Ca}^{2+}$ overload. 


\section{Introduction}

Ion channels are present in endomembranes. These channels are thought to play an important role in cellular processes such as compensation for electrical charges, generation of a $\mathrm{pH}$ gradient [1], oxidative stress production [2,3], and cell volume regulation.

Potassium channels have also been found in endo/sarcoplasmic reticulum membranes. Evidence for a $\mathrm{K}^{+}$selective channel of high conductance was provided by Picard et al. (2002) [4] using sarcoplasmic reticulum (SR) membrane preparations from human (193 pS) and sheep $(185 \mathrm{pS})$ atrial cells. The gating behaviour and permeation properties of this channel were unaffected by the addition of 4-AP and iberiotoxin (IbTx; a specific blocker of Maxi- $\mathrm{K}_{\mathrm{Ca}}$ channels) [4]. Voltage-gated potassium channels were also identified in the SR of diaphragm [5] and frog skeletal muscle [6]. In diaphragm SR the channel conductance and gating properties were not affected by physiological concentrations of $\mathrm{Ca}^{2+}, \mathrm{Mg}^{2+}$, and the channel appeared insensitive to glyburide (a selective blocker of ATP-sensitive $\mathrm{K}+$ channels), and charybdotoxin (ChTx) (blocker of $\mathrm{Ca}^{2+}$-activated $\mathrm{K}^{+}$channels) [5]. It was proposed on the basis of these observations that $\mathrm{SR} \mathrm{K}^{+}$channels could serve in maintaining the $\mathrm{Ca}^{2+}$ homeostasis $[5,7]$.

In contrast to the SR, where voltage gated potassium channels have clearly been identified, there is little evidence for voltage activated $\mathrm{K}^{+}$selective channels in the rough endoplasmic reticulum (RER) of non-excitable cells such as hepatocytes. We have shown in a previous work that the RER membrane of hepatocytes contains a large conductance (509 pS) $\mathrm{K}^{+}$channel activated by voltage and inhibited by $4-\mathrm{AP}(5 \mathrm{mM})$ [8]. Notably channel activity was decreased in presence of ATP $100 \mu \mathrm{M}$ on the cytoplasmic side and totally inhibited at ATP concentrations greater than $0.25 \mathrm{mM}$ [9]. These observations argue for the potential presence of a $\mathrm{K}_{\mathrm{ATP}}$ channel in the RER membranes of hepatocytes. It was reported however that the activity of several Maxi- $\mathrm{K}_{\mathrm{Ca}}$ channels could be altered by intracellular ATP [10]. Of particular interest is the observation that the Maxi- $\mathrm{K}_{\mathrm{Ca}}$ channel we identified in a mitochondrial inner membrane preparation from rat brain was inhibited by $\mathrm{mM} \mathrm{ATP} \mathrm{[11].} \mathrm{These} \mathrm{results} \mathrm{thus} \mathrm{raise} \mathrm{the} \mathrm{possibility} \mathrm{for}$ the presence in internal organelles, including RER, of large conductance $\mathrm{K}^{+}$channels sensitive to ATP not corresponding to $\mathrm{K}_{\mathrm{ATP}}$ type channels. A study was thus undertaken to determine the nature of the ATP sensitive channel we identified in RER of hepatocytes. Our results indicated that the large conductance channels we characterized in RER of hepatocytes correspond to a $\mathrm{K}_{\mathrm{ATP}}$ channel.

\section{Materials and Methods}

\section{Ethical statement}

All experiments were executed in accordance with the Guide for Care and Use of Laboratory Animals (National Institute of Health Publication No.80-23, revised 1996), as approved by the Research and Ethics Committee of Shahid Beheshti University of Medical Sciences (1100/1-87/ $11 / 21 ; 2008)$. Male Wister rats $(180-210 \mathrm{~g})$ were housed in a controlled environment (temperature $22 \pm 2$ _C, humidity $50 \pm 10 \%$ and 12:12-h light/dark cycle) and were acclimatized for a week before use in experiments. Rats had free access to food and water ad libitum.

\section{Materials}

L-a-phosphatidylcholine (L-a-lecithin) was extracted from fresh egg yolk as previously described [12]. 4-(2-hydroxyethyl)-1-piperazine ethane sulfonic acid (HEPES), 2-Amino-2(hydroxymethyl)-1,3-propanediol (Trisma base), potassium chloride, tetraethyl ammonium (TEA), ChTx, IbTx, ATP, glibenclamide, tolbutamide and 4-AP were purchased from Sigma (St Louis, MO, USA) and n-decane was obtained from Merck (Darmstadt, Germany). 


\section{Preparation of membrane vesicles}

Rough microsomes derived from RER of rat liver cells were prepared as previously described $[13,14]$. Briefly, three rats were anesthetised and euthanized by decapitation and then, livers were rapidly removed and homogenized in $30 \mathrm{ml}$ of an ice-cold sucrose $(0.25 \mathrm{M})$ solution at 2850 RPM using potter homogenizer (stage 1 for Western blotting). After adding $60 \mathrm{ml}$ of icecold sucrose $(0.25 \mathrm{M})$ solution, the homogenate was centrifuged at $8700 \times \mathrm{g}$ for $13 \mathrm{~min}$ (stage 2 for Western blotting). Thereafter, the supernatant was centrifuged at $110000 \times \mathrm{g}$ for $60 \mathrm{~min}$ at $4^{\circ} \mathrm{C}$ (Beckman model J-21B, USA). After dissolving the pellet in $9 \mathrm{ml}$ of ice-cold sucrose $2 \mathrm{M}$, the solution was transferred to a $30 \mathrm{ml}$ glass homogenizer, and was manually homogenized 8-10 times to obtain a homogenous suspension. The suspension was subsequently centrifuged at $300000 \times \mathrm{g}$ for $60 \mathrm{~min}$ in a sucrose gradient, and the resulting pellet dissolved in $20 \mathrm{ml}$ of sucrose $0.25 \mathrm{mM}+$ imidazole $3 \mathrm{mM}+\mathrm{Na}$ pyrophosphate $0.5 \mathrm{mM}$ (stage 3 for Western blotting), and centrifuged three times at $140000 \times \mathrm{g}$ for $40 \mathrm{~min}$. The resulting pellet (RER microsomes) was dissolved in $1 \mathrm{ml}$ sucrose $0.25 \mathrm{mM}+$ imidazole $3 \mathrm{mM}$ at a final concentration of $7 \mathrm{mg} / \mathrm{ml}$ (stage 4 for Western blotting). Rough microsomes were stored in $10 \mu \mathrm{l}$ aliquots in $250 \mathrm{mM}$ sucrose $/ 3 \mathrm{mM}$ imidazole, $\mathrm{pH} 7.4$ at $-80^{\circ} \mathrm{C}$ for one month.

\section{Immunoblot analysis}

Protein samples $(35 \mu \mathrm{g})$ from each fraction were subjected to SDS-PAGE $(n=3)$ blotted and probed with antibodies directed against specific marker proteins: cox1 (Santa Cruz, SC-58347; Santa Cruz Biotechnology Inc., Heidelberg, Germany), actin (Santa Cruz, SC-1615), calnexin (Santa Cruz, SC-11397), 58 K Golgi protein (abcam, ab6284, Cambridge, UK)), SUR1 (Santa Cruz, SC-5789), SUR2A and SUR2B s (Santa Cruz, SC-32462 and SC-5793, respectively) and Kir6.2 (Santa Cruz, SC-11228; Santa Cruz Biotechnology Inc., Heidelberg, Germany). Expressions of the $\mathrm{BK}_{\mathrm{Ca}}$ channel $\alpha$-subunit in rat hepatocyte endoplasmic reticulum was determined using an antibody directed against $\mathrm{BK}_{\mathrm{Ca}}$ channel $\alpha$-subunit (rabbit polyclonal antibody, $\mathrm{AB}$ 104467, Abcam, Cambridge, UK). Secondary antibodies linked to horseradish peroxidase were obtained from GE-Biosciences. Blots were finally treated with ECL kit for chemiluminescence detection.

\section{Bilayer formation and vesicle fusion}

Planar phospholipid bilayers were formed in a $300 \mu \mathrm{m}$-diameter hole. The cis (cytoplasmic side) and trans (luminal side) chambers held $4 \mathrm{ml}$ of $\mathrm{KCl} 200$ and $50 \mathrm{mM}$ (pH 7.4), respectively. Planar phospholipid bilayers were painted using a suspension of L-a-lecithin in decane (25 $\mathrm{mg} / \mathrm{ml}$ ). Fusion of the vesicles was initiated mechanically by gently touching the bilayer from the cis side.

\section{Recording instrumentation and statistical analysis}

Single channel currents were measured with a BC-525D amplifier (Warner Instrument, USA). The cis chamber was voltage-clamped relative to the trans chamber, which was grounded. Electrical connections were made by using $\mathrm{Ag} / \mathrm{AgCl}$ electrodes and agar salt bridges. All recordings were filtered at $1 \mathrm{kHz}$ digitized at a sampling rate of $10 \mathrm{kHz}$ and stored on a personal computer for off line analysis using PClamp9 (Axon Instruments Inc, USA). Unitary channel conductance was calculated from the current-voltage relationship. Open channel probability $\left(\mathrm{P}_{\mathrm{o}}\right)$ was calculated using the standard event detection algorithms in PClamp9. $\mathrm{P}_{\mathrm{o}}$ was calculated from segments of continuous recordings lasting $50 \mathrm{~s}$. The significance of differences was determined by Student's t test. Data are expressed as mean \pm S.E. (standard error). 


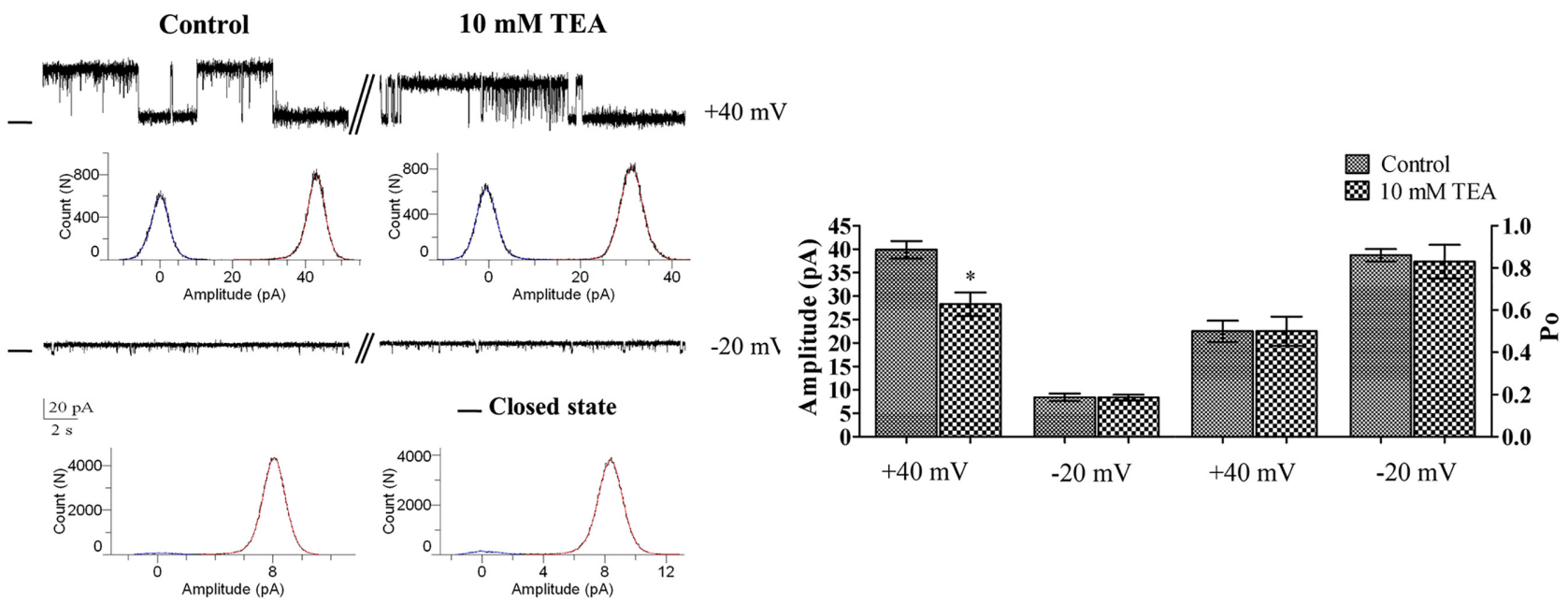

Fig 1. The effect of $\mathrm{TEA}^{+}$on channel gating behavior at $+\mathbf{4 0}$ and $\mathbf{- 2 0} \mathbf{~ m V}$. Examples of single channel recordings in controlled conditions (200/50 mMKCl; cis/trans) and immediately after cis addition of TEA $10 \mathrm{mM}$. Addition of TEA ${ }^{+}$to the cis chamber caused a voltage dependent reduction in current jump amplitude that was significant at $+40 \mathrm{mV}$. Results of these experiments are summarized in the bar graph shown in the right panel. Data are means \pm S.E. $(n=3)$. The-shows the closed levels and * indicates $P \leq 0.05$.

doi:10.1371/journal.pone.0125798.g001

\section{Results}

The nature of the large conductance $\mathrm{K}^{+}$channel we previously identified in the RER membrane of hepatocyte [8] was investigated in a series of experiments aimed first to characterize the channel pharmacological profile, and second to establish if the $\mathrm{K}_{\mathrm{ATP}}$ Kir6.x and SUR subunits were present in our RER membrane preparation.

\section{Effect of a nonspecific $\mathrm{K}^{+}$channel blocker, $\mathrm{TEA}^{+}$}

Fig 1 shows that the addition of $10 \mathrm{mM} \mathrm{TEA}^{+}$to cis chamber significantly reduced the channel unitary current amplitude at positive potentials (Fig $1, n=3$ ). This result is compatible with the expected effect of a fast blocking agent.

\section{Effect of calcium ions and $\mathrm{Ca}^{2+}$-dependent $\mathrm{K}^{+}$channels blockers, $\mathrm{ChTx}$ and $\mathrm{IbTx}$}

We have already shown that the large conductance $\mathrm{K}^{+}$channels in RER are inhibited by ATP in a dose-dependent manner [9]. Since, both Maxi- $\mathrm{K}_{\mathrm{Ca}}$ and $\mathrm{K}_{\mathrm{ATP}}$ channels are sensitive to ATP, we considered the possible effect of $\mathrm{Ca}^{2+}$ ions and Maxi- $\mathrm{K}_{\mathrm{Ca}}$ blockers on the $\mathrm{K}^{+}$channel from RER membranes. Fig 2A-2C show examples of single channel recordings obtained at -20 $\mathrm{mV}$. Changes in channel activity were not observed after addition of $1 \mathrm{mM}$ EGTA, arguing for the $\mathrm{K}^{+}$channel we identified in the RER not being $\mathrm{Ca}^{2+}$ sensitive (Fig 2A). In addition, cis addition of IbTx $(1 \mu \mathrm{M} ; \mathrm{n}=5)$, a specific inhibitor of Maxi-K $\mathrm{K}_{\mathrm{Ca}}$ channels, and ChTx (800 nM; $\mathrm{n}=4$ ) failed to modify the channel open probability and amplitude (Fig $2 \mathrm{~B}$ and $2 \mathrm{C}$ ). These results are summarized in the bar graph presented in the right panel. Altogether these observations provide evidence for $\mathrm{K}^{+}$channel in RER not corresponding to a Max- $\mathrm{K}_{\mathrm{Ca}}$ channel.

\section{Effect of sulfonylureas on channel activity}

In additional experiments, the effect of glibenclamide and tolbutamide, two well-known sulfonylureas $\mathrm{K}_{\mathrm{ATP}}$ channel blockers, was examined on RER channel activity. Fig 3A shows that the addition of 10 and $25 \mu \mathrm{M}$ glibenclamide on the cis side had no significant effect on the channel 


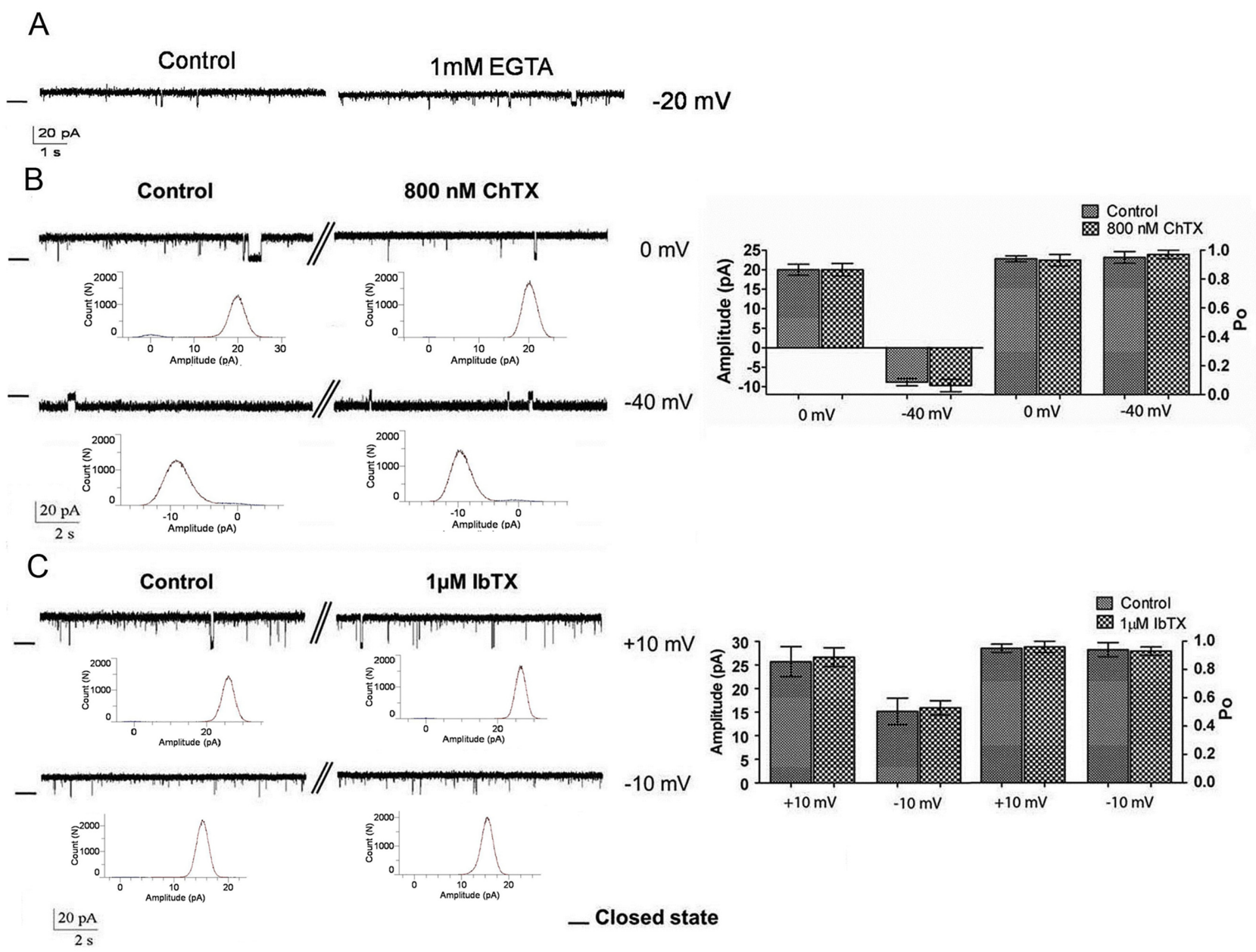

Fig 2. Effect of EGTA, charybdotoxin, and iberitoxin on channel activity. Representative unitary current recordings in control conditions (200/50 mMKCl; cis/trans) and after addition of $1 \mathrm{mM}$ EGTA at $-20 \mathrm{mV}(\mathrm{A}), 800 \mathrm{nM}$ charybdotoxin (cis face) at 0 and $-40 \mathrm{mV}(\mathrm{B})$, and $1 \mu \mathrm{M}$ iberiotoxin at +10 and $-10 \mathrm{mV}(\mathrm{C})$. Data are summarized in the bar graph presented in the right panel. There were no significant differences in open probability and current jump amplitude $\left(n=2, n=4, n=5\right.$, respectively), indicating that the $K^{+}$channel from RER does not correspond to a Max-K $K_{C a}$ channel. The-indicates the closed levels.

doi:10.1371/journal.pone.0125798.g002

Po and current jump amplitude at $0 \mathrm{mV}(\mathrm{n}=2)$, while glibenclamide at $50 \mu \mathrm{M}$ caused a small but significant decrease in the amplitude of the current jump and channel $\mathrm{P}_{\mathrm{o}}$. In contrast a total block of cannel activity was observed with $100 \mu \mathrm{M}$ glibenclamide in the cis chamber at positive but not negative potentials (Fig 3B). These results are summarized in the bar graph presented in the lower panel.

Complementary to these observations the results presented in Fig 4 show that the $\mathrm{K}^{+}$channel from RER was completely inhibited by addition of tolbutamide ( $400 \mu \mathrm{M})$ to the cis compartment at negative and positive potentials $(n=5)$. These observations argue for the $\mathrm{K}^{+}$ channel in RER having the characteristics of a $\mathrm{K}_{\mathrm{ATP}}$ channel.

\section{Western blot analysis of $\mathrm{K}_{\mathrm{ATP}}$ channel subunits}

A Western blot analysis was next conducted to determine if $\mathrm{K}_{\mathrm{ATP}}$ subunits were present in microsomes prepared from rat hepatocytes. We first evaluated the purity of our microsome preparation using antibodies directed against various cellular proteins considered unique to particular subcellular regions (Fig 5A). As seen in Fig 5B, the homogenate (step 1) contains as 
A
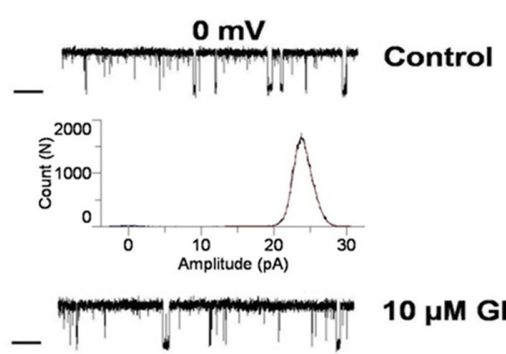

$10 \mu \mathrm{M}$ Glibenclamide
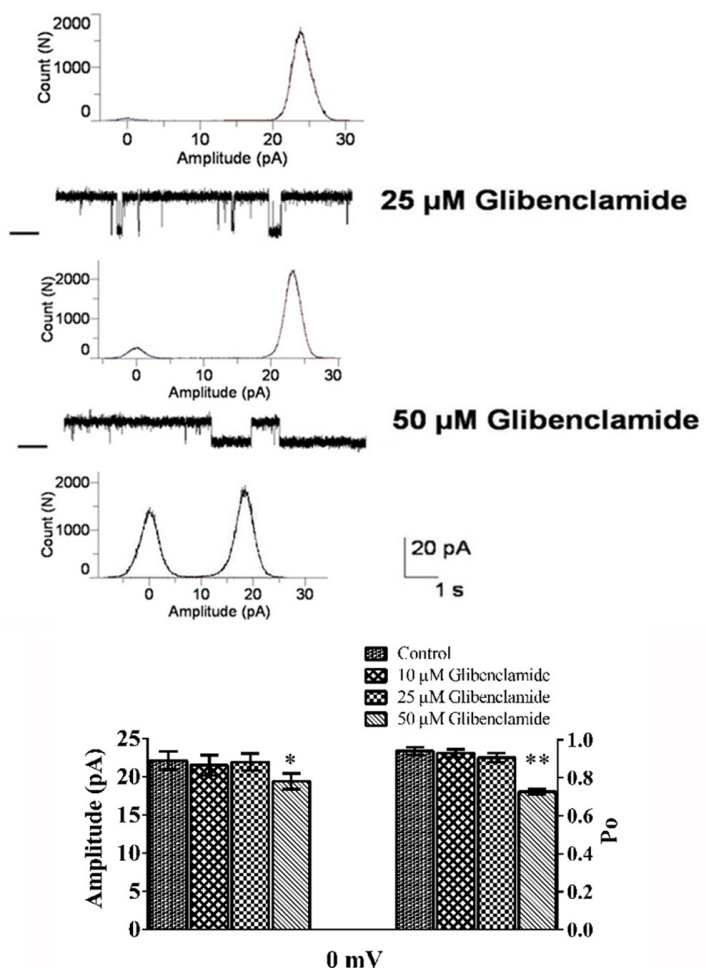

$\mathrm{B}$
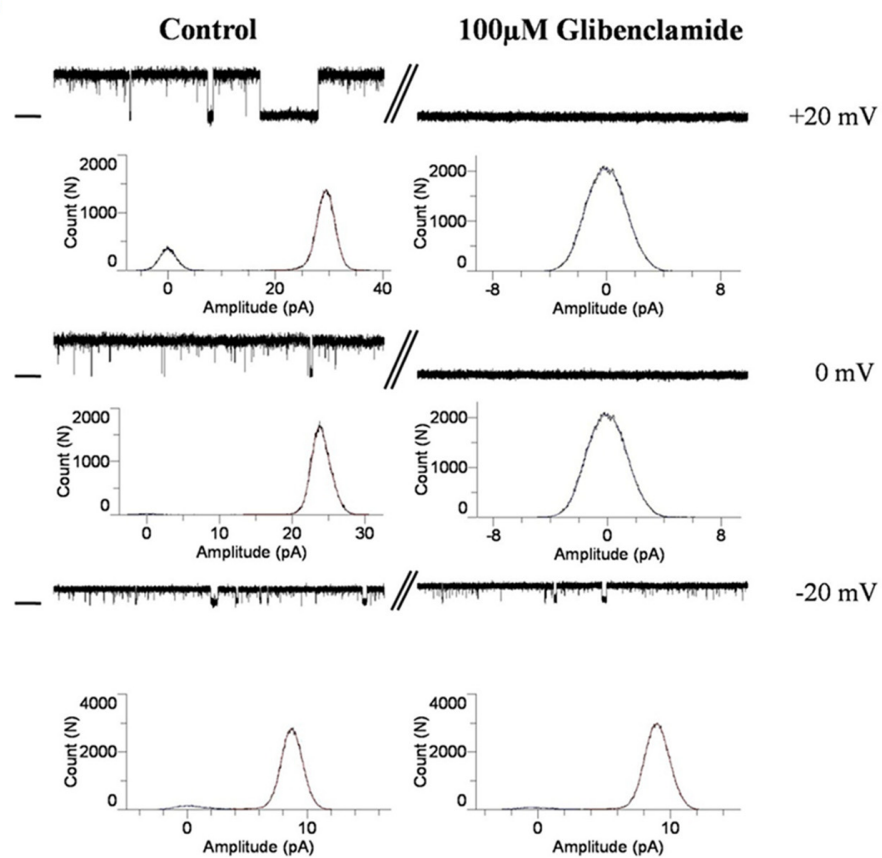

$0 \mathrm{mV}$
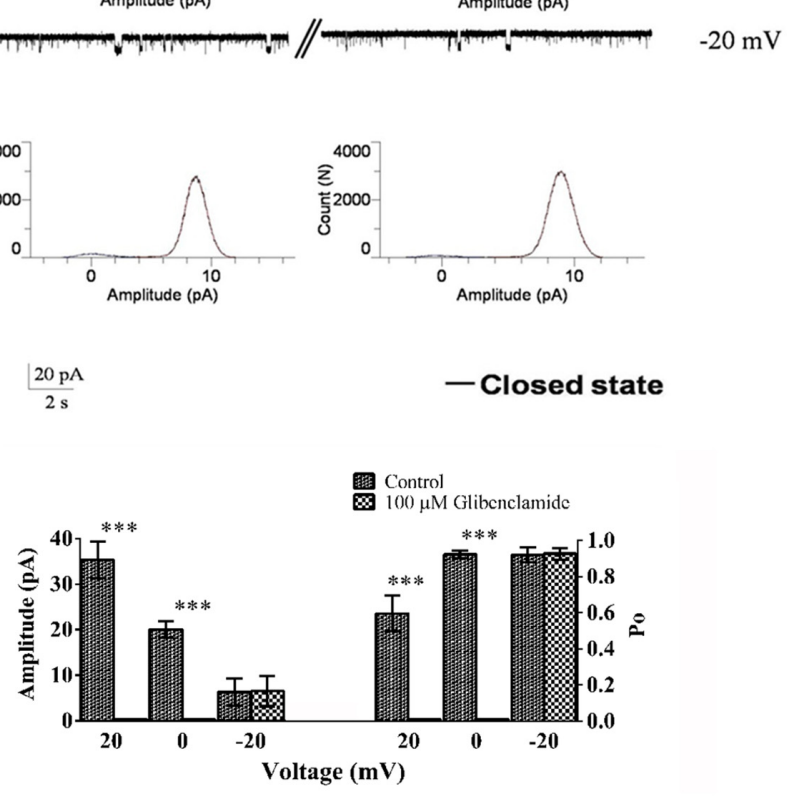

Fig 3. The effect of glibenclamide on channel activity at $+\mathbf{2 0}, \mathbf{0}$ and $-\mathbf{2 0} \mathrm{mV}$. Representative unitary current recordings in control conditions (200/50 $\mathrm{mMKCl}$; cis/trans) and after cis addition of $10,25,50(\mathrm{~A})$ or $100 \mu \mathrm{M}$ glibenclamide $(\mathrm{B})$ at different voltages. Histogram bars show current amplitudes and $\mathrm{P}_{\mathrm{o}}$ of reconstituted channels in absence or presence of glibenclamide. The addition of $50 \mu \mathrm{M}$ glibenclamide resulted in a decreased current jump amplitude and a reduction in $P_{0} .100 \mu \mathrm{M}$ glibenclamide caused a total channel inhibition at +20 and $0 \mathrm{mV}(\mathrm{n}=5)$, but was ineffective at $-20 \mathrm{mV}$. The significant difference in the channel amplitude and $P_{0}$ values are marked by asterisks $\left({ }^{*} P<0.05\right.$ and ${ }^{*}{ }^{*} P_{0}<0.01$, respectively, $\left.n=5\right)$. Data are means $\pm S$.E. Closed levels are indicated by - .

doi:10.1371/journal.pone.0125798.g003

expected mitochondrial inner membrane the quantity of which was substantially reduced in final step (step 4) of RER membrane preparation.

We next probe for the presence of $\mathrm{K}_{\mathrm{ATP}}$ subunits in our RER microsome preparations using antibodies directed against the $\mathrm{K}_{\mathrm{ATP}}$ Kir6.2, SUR1, SUR2A, and SUR2B subunits. Labelling with the anti Kir6.2 antibody showed a specific band at $55 \mathrm{kDa}$, a molecular weight corresponding to the molecular weight estimated for Kir6.2 (Fig 6A) $(n=4)$. The results presented in Fig 6B indicate in addition that the anti-SUR2A antibody could labelled a $150 \mathrm{kDa}$ band in crude and RER fractions, whereas two distinct bands at $100 \mathrm{kDa}$ and $150 \mathrm{kDa}$ were detected using the anti-SUR2B and anti-SUR1 antibodies in both the homogenate and RER membrane preparation respectively. These data confirm the presence of the $\mathrm{K}_{\mathrm{ATP}}$ Kir6.2, SUR1 and SUR2 $A$ and $B$ subunits in the RER membrane fraction used for channel incorporation. We also 


\section{Control $\quad 400 \mu \mathrm{M}$ Tolbutamide}
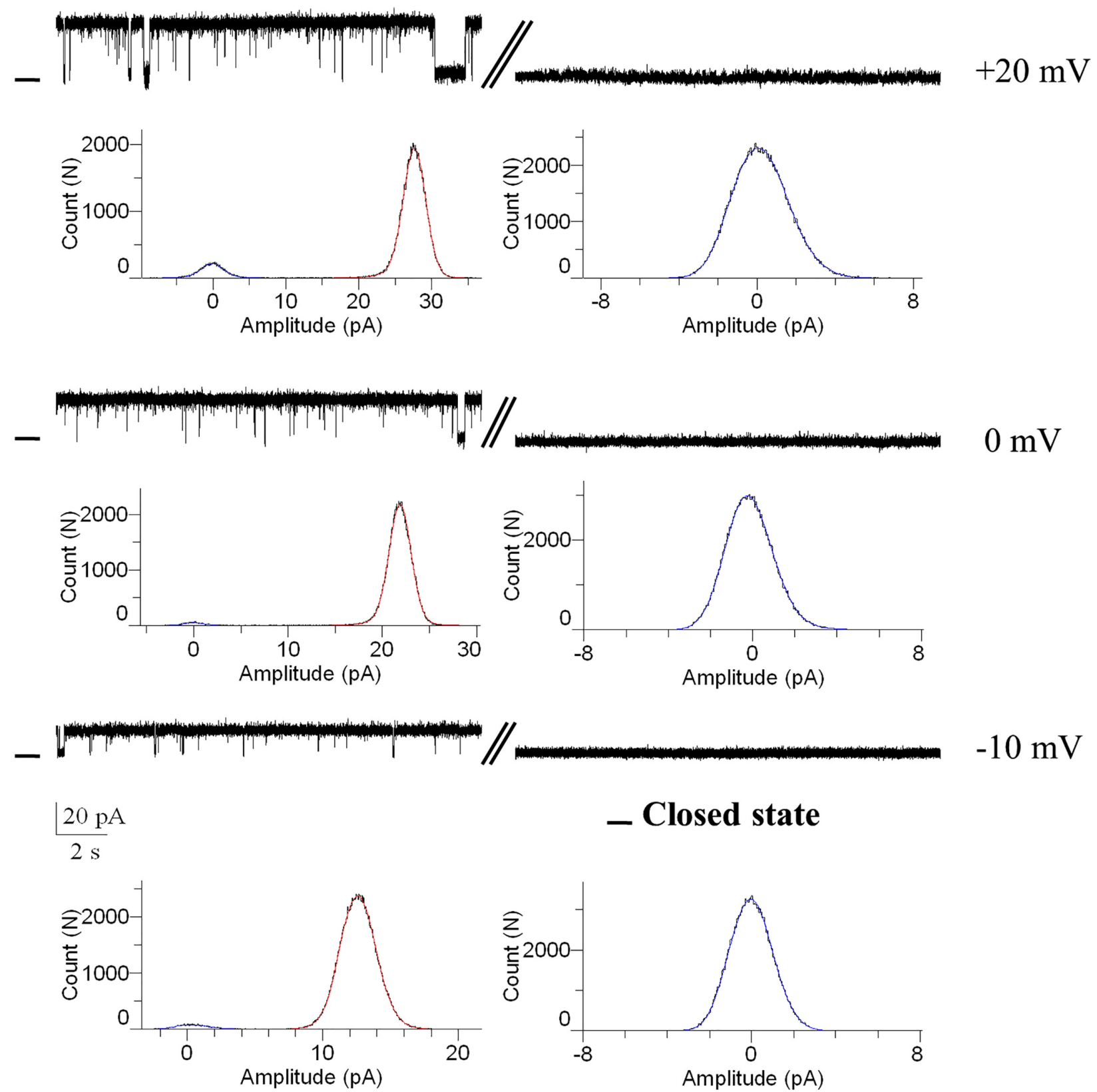

Fig 4. Effect of tolbutamide on channel gating behavior at $+\mathbf{2 0}, \mathbf{0}$ and $\mathbf{- 1 0} \mathrm{mV}$. Examples of single channel recordings in control conditions (200/50 $\mathrm{mMKCl}$; cis/trans), and immediately after cis addition of tolbutamide $400 \mu \mathrm{M}(\mathrm{n}=5)$. Tolbutamide caused a total voltage independent inhibition of channel activity. The-indicates the closed levels.

doi:10.1371/journal.pone.0125798.g004

tested for the presence of $\mathrm{BK}_{\mathrm{Ca}}$ channel protein in the endoplasmic reticulum membrane [15, 16]. The immunoblot presented in Fig $6 \mathrm{C}$ indicates in this regard that the $\mathrm{BK}_{\mathrm{Ca}}$ channel $\alpha$ subunits protein is expressed in our endoplasmic reticulum membrane preparation, despite the absence of detectable $\mathrm{BK}_{\mathrm{Ca}}$ channel activity in our incorporation experiments. 
A

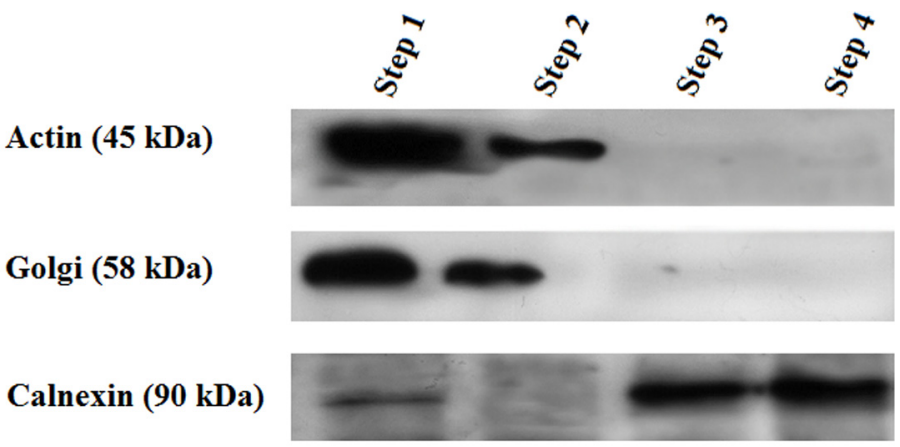

B

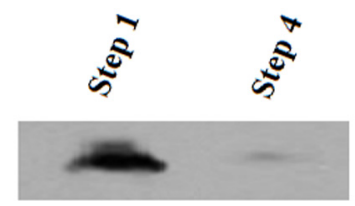

Fig 5. Characterization of the cell fraction used for channel incorporation. Membranes were probed with organelle specific antibodies. A) Plasma membrane marker: Actin (C-11), $45 \mathrm{kDa}$; Golgi marker: $58 \mathrm{~K}$ Goli protein; endoplasmic reticulum marker: Calnexin, $90 \mathrm{kDa}$, and in B) Mitochondrial membrane marker: Cox1 (1D6), $39 \mathrm{kDa}$. Although mitochondrial membranes were present in the homogenate (step 1) these membranes were removed through the purification procedure we used to obtain RER membranes (step 4). Steps 1 and 4 are described in the "methods and materials" section.

doi:10.1371/journal.pone.0125798.g005

\section{Discussion}

$\mathrm{K}_{\mathrm{ATP}}$ channels were originally discovered in the heart, and have since been found in numerous tissue preparations $[17,18] . \mathrm{K}_{\mathrm{ATP}}$ channels are also present in endomembranes, in particular in mitochondria (mitoK $\mathrm{ATP}_{\mathrm{A}}$ [19]. The main functional feature of $\mathrm{K}_{\mathrm{ATP}}$ channels arises from

A

Kir6.2 (55 kDa)
ER

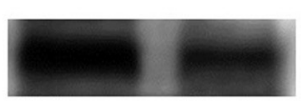

B

$\mathbf{H}$

ER

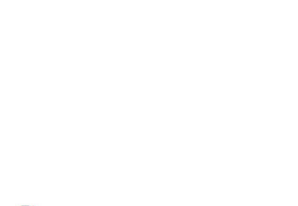

C

a. -subunit (138 kDa)
ER

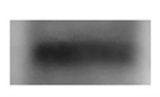

SUR2A

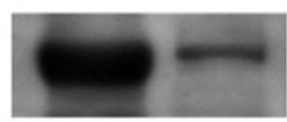

$150 \mathrm{kDa}$

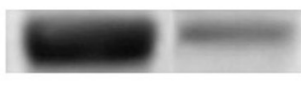

$150 \mathrm{kDa}$

SUR2B

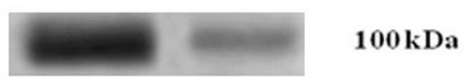

$100 \mathrm{kDa}$

$150 \mathrm{kDa}$

SUR1
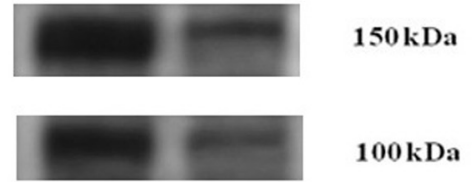

Fig 6. Western blot analysis of Kir6.2 and SURs in the rat microsome fractions. (A) The goat anti-Kir6.2 antibody led to the identification of a prominent $\sim 55 \mathrm{kDa}$ band in microsome fractions, a molecular weight compatible with a Kir6. $2 \mathrm{~K}_{\text {ATP }}$ subunit. (B) $\sim 150 \mathrm{kDa}$ band was detected using the goat anti-SUR2A antibody, whereas the goat anti-human SUR2B and SUR1 antibodies led to the labeling of two bands of 150 and $100 \mathrm{kDa}$ respectively. The $100 \mathrm{kDa}$ may be resulting from proteolysis of the $150 \mathrm{kDa}$ paptide. (C) Western blot indicating that of the Maxi- $\mathrm{K}_{\mathrm{Ca}}$ channel $\alpha$-subunit (138 kDa) is expressed in rat endoplasmic reticulum membranes.

doi:10.1371/journal.pone.0125798.g006 
their sensitivity to internal ATP levels, with $\mathrm{K}_{\mathrm{ATP}}$ being blocked at submilimolar ATP concentrations. Internal block by ATP is not however exclusive to $\mathrm{K}_{\mathrm{ATP}}$ channels. In fact, several studies have shown that Maxi- $\mathrm{K}_{\mathrm{Ca}}$ channels could be inhibited by intracellular ATP [10, 20, 21]. In this regard we have presented evidence that a Maxi- $\mathrm{K}_{\mathrm{Ca}}$ channel in the inner membrane of mitochondria could be blocked by internal ATP in the $\mathrm{mM}$ rage [11]. These observations casted some doubt on the actual nature of a $\mathrm{K}^{+}$channel of large conductance we identified in a RER membrane preparation from hepatocyte as this channel could be inhibited by ATP within the same concentration rage $[8,9]$. We demonstrated in this work through Western blotting analysis and pharmacological characterization that the $\mathrm{K}^{+}$channel of large conductance identified in RER membranes possesses features associated to a $K_{\text {ATP }}$ type channel

The $\mathrm{K}^{+}$channel blocking agent $\mathrm{TEA}^{+}$was first used to probe the rerK ${ }^{+}$channel conduction pathway. TEA acts from both sides of the channels and its blocking action is voltage-dependent $[22,23]$. Our results showed that $10 \mathrm{mM} \mathrm{TEA}^{+}$decreased unitary current amplitude of the $\mathrm{K}^{+}$ channel from RER $\left(\right.$ RERK $\left.^{+}\right)$at positive voltages, a result compatible with a fast block mechanism. These results do not however enable one to discriminate between $\mathrm{K}_{\mathrm{ATP}}$ and Maxi- $\mathrm{K}_{\mathrm{Ca}}$ channels as TEA $^{+}$was found to block Maxi- $\mathrm{K}_{\mathrm{Ca}}$ channels [20, 21], albeit at lower concentrations than those reported to block $\mathrm{K}_{\mathrm{ATP}}$.

Several pharmacological blockers of Maxi- $\mathrm{K}_{\mathrm{Ca}}$ channels are known, including the scorpionderived peptides ChTx and IbTx [24, 25]. In the current study, we showed that addition of IbTx and ChTx to the cis side did not affect the channel activity, thus confirming that the channel does not belong to Maxi- $\mathrm{K}_{\mathrm{Ca}}$ channel family. This conclusion is further supported by the observation that the channel remained active in zero $\mathrm{Ca}^{2+}$ conditions. Notably the high conductance Slack ('sequence like a $\mathrm{Ca}^{2}+$-activated $\mathrm{K}^{+}$channel; also termed Slo2.2) and Slik (also termed Slo2.1) [26], sodium-activated $\mathrm{K}^{+}\left(\mathrm{K}_{\mathrm{Na}}\right)$ channels [27-29] have been documented to be insensitive to the Maxi- $\mathrm{K}_{\mathrm{Ca}}$ channel blocking agent iberiotoxin but inhibited by $\mathrm{TEA}^{+}$at the millimolar $(10 \mathrm{mM})$ concentration range $[26,28]$. More importantly, application of ATP to the cytoplasmic face of Slick channels was found to reduce channel activity [28]. These features are in line with the pharmacological profile we obtained for the $\mathrm{K}^{+}$in RER membranes. It has been suggested that the $\mathrm{Na}^{+}$concentration required for channel gating in both cases ranges from 7 $\mathrm{mM}$ to $180 \mathrm{mM}$ [29]. As all our experiments were performed at contaminant levels of $\mathrm{Na}^{+}(\approx$ $100 \mu \mathrm{M})$, the possibility that the $\mathrm{K}^{+}$channel from RER corresponds to either Slo2.1 or Slo2.2 can be ruled out. However observations by Kim et al. (2007) [30] indicated that $\mathrm{K}_{\mathrm{Na}}$ channels could not be inhibited in the presence of a $\mathrm{K}^{+}$channel blocker cocktail containing a mixture of $\mathrm{Ba}^{2+}$, glibenclamide, 4-AP, apamin, and quinidine [30], a result incompatible with the blocking effect of glibenclamide we observed on the $\mathrm{K}^{+}$channel from RER membrane.

Sulfonylurea compounds are known to bind to the SUR subunit and inhibit the $\mathrm{K}_{\mathrm{ATP}}$ channel activity [31, 32]. To determine if the endoplasmic reticulum potassium channel in rat hepatocytes corresponds to $\mathrm{K}_{\mathrm{ATP}}$ channel, we tested the effects of a cis application of tolbutamide and glibenclamide on channel activity. Fig 4 demonstrates that the addition of $400 \mu \mathrm{M}$ of tolbutamide to the cytoplasmic side (cis chamber) completely blocked channel activity. Furthermore, our result showed that glibenclamide at $100 \mu \mathrm{M}$ inhibited the channel activity at positive potentials, but failed to affect the channel unitary current amplitude and open probability at negative potentials. The mechanism by which glibenclamide inhibits the ATP sensitive $\mathrm{K}^{+}$ channel in RER remains to be established. It has been suggested that glibenclamide was not blocking the channel directly but might act by binding either to the voltage gate and/or to the inner mouth of the channel leading to enhanced hydrophobic interactions between the two and a stabilization of the channel inactivated state [33]. Inhibition of channel activity by glibenclamide and tolbutamide was in the present work observed at micromolar concentrations. Notably, the $\mathrm{K}_{\mathrm{ATP}}$ channel sensitivity to sulfonylurea derivatives was found to vary over a three 
orders of magnitude depending on the cell type. For instance $K_{\text {ATP }}$ channels in pancreatic $\beta$ cells, cardiac muscle, and brain were found to be inhibited by glibenclamide at nanomolar concentrations, whereas $\mathrm{K}_{\mathrm{ATP}}$ channels in other cells including epithelial cells appeared more glibenclamide resistant with concentrations for half- inhibition in the micromolar to millimolar ranges [34-36]. It has been suggested that the cytoskeleton affected $\mathrm{K}_{\mathrm{ATP}}$ channel sensitivity to sulfonylureas inhibition, with a disruption of cytoskeleton structure by DNasel leading to a 20 folds decrease in sulfonylureas affinities to $\mathrm{K}_{\mathrm{ATP}}$ [37]. Because ER extraction involves disruption of the cell cytoskeleton it is possible that the low affinity we observed for glibenclamide and tolbutamide induced channel inhibition partly arised for the absence of cytoskeleton. Altogether, our pharmacological results would support the presence of a $\mathrm{K}_{\mathrm{ATP}}$ channel in the hepatocytes RER membrane.

$\mathrm{K}_{\mathrm{ATP}}$ channels are octomeric structures comprising four pore-forming Kir6.1 or Kir6.2 subunits and four sulfonylurea receptors (SURs) encoded by two distinct genes, SUR1 and SUR2 (SUR2A and SUR2B). Kir6.2 was reported to be expressed in ER fractions of pancreatic beta cells [38] and cardiomyocytes [39]. Our current Western blot results also argue for Kir6.2 being present in the RER membrane of hepatocytes and for the presence of the SUR1, SUR2A, and SUR2B subunits (Fig 6). Our Western blot results are unlikely to be explained by the presence of contaminants coming from other subcellular compartments, as we failed to detect the expression of plasma membrane or Golgi matrix specific proteins in our microsomal preparations. To our knowledge, this is the first study addressing the combination of SURs subunits in endoplasmic reticulum of rat hepatocytes.

There is evidence that the sensitivity of the channel to different sulfonylureas could depend on the SUR isoform. For instance, Kir6.2-SUR1 but not Kir6.2-SUR2A channels are blocked by tolbutamide with high affinity [40,41]. Glibenclamide blocks both types of channels with high affinity. In line with these observations, reconstitution of $\mathrm{K}_{\mathrm{ATP}}$ channels by co-expression of Kir6.2 and SUR2 in COS cells, and sulfonylurea binding measurements have revealed that despite similar structural features between SUR2 and SUR1, SUR2 binds glibenclamide with a lower affinity compared to SUR1, demonstrating that different responses to sulfonylureas may be linked to the SUR isoform [42]. These data, added to the fact that glibenclamide consists in a tolbutamide moiety plus a non-sulfonylurea meglitinide group known to inhibit $\mathrm{K}_{\mathrm{ATP}}$ channels $[43,44]$ suggest that SUR1 contains a high-affinity tolbutamide- binding site missing in SUR2A. Our Western blot analysis provided unambiguous evidence for the presence of the Kir6.2 and SUR2A $\mathrm{K}_{\text {ATP }}$ subunits in the RER membrane of hepatocytes. Our analysis also showed two bands of $150 \mathrm{kDa}$ and $100 \mathrm{kDa}$ for the SUR2B and SUR1 subunits. It has been reported that the antiSUR2B anti-body recognises polypeptides of different molecular weights $(150,100$, and $55 \mathrm{kDa})$ in some microsomal fractions including microsomes from rat heart sarcolemmal membranes [45]. More importantly, since the sequences of antigen peptide in SUR2B are highly homologous to the corresponding region in SUR1, we cannot currently rule out the possibility that the bands assigned to SUR2B can also be assigned to SUR1 [45]. Our results thus suggest that Kir6.2 and SUR2A are expressed in RER membrane of hepatocyte together with SUR2B and/or SUR1. There are supporting data that SUR1 and SUR2A coassemble readily and randomly to form heteromeric $\mathrm{K}_{\mathrm{ATP}}$ channels [46]. Furthermore, Wheeler et al. demonstrated that SUR1, SUR2A, and SUR2B can coassemble in all the possible pair-wise combinations to form functional $\mathrm{K}_{\mathrm{ATP}}$ channels with distinct properties, resulting in an enhanced functional and pharmacological diversity [46]. Determination of the Kir6.2 and SUR subunits exact combination will require further investigation.

Several groups $[15,16]$ including ours (present work) have provided evidence for the presence of the $\mathrm{BK}_{\mathrm{Ca}}$ channel $\alpha$-subunit (pore-forming subunit) in endoplasmic reticulum membrane. Notably channel activity could not be detected at single channel level in these 
preparations. These observations contrast with results obtained from mitochondria and nucleus membranes where $\mathrm{BK}_{\mathrm{Ca}}$ channel activity has been documented $[47,48,11]$. We cannot currently rule out the possibility of a non functional $\mathrm{BK}_{\mathrm{Ca}}$ isofrom present in our RER membrane preparation. Confirmation of this proposal will await further work.

The precise functional role of $\mathrm{K}_{\mathrm{ATP}}$ channels in RER is currently unknown. Both SR/ER Cl and $\mathrm{K}^{+}$channels act as counter transport systems during rapid $\mathrm{Ca}^{2+}$ release and uptake as to keep electroneutrality and maintain the electrochemical driving force acting on $\mathrm{Ca}^{2+}$ ions [49, 50]. Given that $\mathrm{Ca}^{2+}$ regulations by the ER is prominent in cellular apoptosis [51, 52], these data suggest that $\mathrm{K}_{\mathrm{ATP}}$ in RER membrane channel may contribute to the regulation of ERmediated cellular mortality so that a defect in this regulatory process may cause a progressive loss of cell function and the generation of a cellular pathological state.

\section{Acknowledgments}

We thank Dr. F. Khodagholi for help in Western blotting analysis.

\section{Author Contributions}

Conceived and designed the experiments: AE. Performed the experiments: SS MG JFB R. Saghiri. Analyzed the data: SS MG AE. Wrote the paper: AE. Critical revision of the manuscript for important intellectual content: R. Sauve.

\section{References}

1. Edwards JC, Kahl CR. Chloride channels of intracellular membranes. FEBS Lett. 2010; 584: 2102-2111. doi: 10.1016/j.febslet.2010.01.037 PMID: 20100480

2. Averaimo S, Milton RH, Duchen MR, Mazzanti M. Chloride intracellular channel 1 (CLIC1): Sensor and effector during oxidative stress. FEBS Lett. 2010; 584: 2076-2084. doi: 10.1016/j.febslet.2010.02.073 PMID: 20385134

3. Malinska D, Mirandola SR, Kunz WS. Mitochondrial potassium channels and reactive oxygen species. FEBS Lett. 2010; 584: 2043-2048. doi: 10.1016/j.febslet.2010.01.013 PMID: 20080090

4. Picard L, Cote K, Teijeira J, Greentree D, Rousseau E. Sarcoplasmic reticulum K(+) channels from human and sheep atrial cells display a specific electro-pharmacological profile. J Mol Cell Cardiol. 2002; 34: 1163-1172. PMID: 12392890

5. Picher M, Decrouy A, Rousseau E. Conducting and voltage-dependent behaviors of potassium ion channels reconstituted from diaphragm sarcoplasmic reticulum: comparison with the cardiac isoform. Biochim Biophys Acta. 1996; 1279: 93-103. PMID: 8624367

6. Wang J, Best PM. Characterization of the potassium channel from frog skeletal muscle sarcoplasmic reticulum membrane. J Physiol. 1994; 477: 279-290. PMID: 7932219

7. Ng KE, Schwarzer S, Duchen MR, Tinker A. The intracellular localization and function of the ATPsensitive K+ channel subunit Kir6.1. J Membr Biol. 2010; 234: 137-147. doi: 10.1007/s00232-0109241-x PMID: 20306027

8. Sepehri H, Eliassi A, Sauve R, Ashrafpour M, Saghiri R. Evidence for a large conductance voltage gated cationic channel in rough endoplasmic reticulum of rat hepatocytes. Arch Biochem Biophys. 2007; 457: 35-40. PMID: 17118328

9. Ashrafpour M, Eliassi A, Sauve R, Sepehri H, Saghiri R. ATP regulation of a large conductance voltage-gated cation channel in rough endoplasmic reticulum of rat hepatocytes. Arch Biochem Biophys. 2008; 471: 50-56. doi: 10.1016/j.abb.2007.12.012 PMID: 18187033

10. Hirano J, Nakamura K, Kubokawa M. Properties of a $\mathrm{Ca}(2+)$-activated large conductance $\mathrm{K}(+)$ channel with ATP sensitivity in human renal proximal tubule cells. Jpn J Physiol. 2001; 51: 481-489. PMID: 11564285

11. Fahanik-Babaei J, Eliassi A, Saghiri R. How many types of large conductance $\mathrm{Ca}^{+2}$-activated potassium channels exist in brain mitochondrial inner membrane: evidence for a new mitochondrial large conductance Ca+2-activated potassium channel in brain mitochondria. J Neurosci. 2011; 199: 125-132.

12. Singleton WS, Gray MS, Brown ML, White JL. Chromatographically homogeneous lecithin from egg phospholipids. J Am Oil Chem Soc. 1965; 42: 53-56. PMID: 14228472 
13. Eliassi A, Garneau L, Roy G, Sauve R. Characterization of a chloride-selective channel from rough endoplasmic reticulum membranes of rat hepatocytes: evidence for a block by phosphate. J Membr Biol. 1997; 159: 219-229. PMID: 9312211

14. Kan FW, Jolicoeur M, Paiement J. Freeze-fracture analysis of the effects of intermediates of the phosphatidylinositol cycle on fusion of rough endoplasmic reticulum membranes. Biochim Biophys Acta. 1992; 1107: 331-341. PMID: 1504076

15. Zarei MM, Eghbali M, Alioua A, Song M, Knaus HG, Stefani E, et al. An endoplasmic reticulum trafficking signal prevents surface expression of a voltage- and $\mathrm{Ca} 2+$-activated $\mathrm{K}+$ channel splice variant. Proc Natl Acad Sci U S A. 2004; 101: 10072-10077. PMID: 15226510

16. Ma D, Nakata T, Zhang G, Hoshi T, Li M, Shikano S, et al. Differential trafficking of carboxyl isoforms of Ca2+-gated (Slo1) potassium channels. FEBS Lett. 2007; 581: 1000-1008. PMID: 17303127

17. Noma A. ATP-regulated K+ channels in cardiac muscle. Nature. 1983; 305: 147-148 PMID: 6310409

18. Ballanyi $K$. Protective role of neuronal $K_{A T P}$ channels in brain hypoxia. J Exp Biol. 2004; 207: 3201-3212. PMID: 15299041

19. Inoue I, Nagase $\mathrm{H}$, Kishi K, Higuti T. ATP-sensitive $\mathrm{K}^{+}$channel in the mitochondrial inner membrane. Nature. 1991; 352: 244-247. PMID: 1857420

20. Song X, Su W, Chen L, Ji JJ. Functional expression of large-conductance $\mathrm{Ca}^{2+}$-activated potassium channels in lateral globus pallidus neurons. J Neurosci. 2010; 169: 1548-1556.

21. Su W, Song X, Ji JJ. Functional expression of a large-conductance $\mathrm{Ca}^{2+}$-activated $\mathrm{K}^{+}$channel in mouse substantia nigra pars compacta dopaminergic neurons. Neurosci lett. 2010; 471: 1-5. doi: 10. 1016/j.neulet.2009.12.058 PMID: 20036716

22. Kutluay E, Roux B, Heginbotham L. Rapid intracellular TEA block of the KcsA potassium channel. Biophys J. 2005; 88: 1018-1029. PMID: 15556975

23. Lenaeus MJ, Vamvouka M, Focia PJ, Gross A. Structural basis of TEA blockade in a model potassium channel. Nat Struct Mol Biol. 2005; 12: 454-459. PMID: 15852022

24. Galvez A, Gimenez-Gallego G, Reuben JP, Roy-Contancin L, Feigenbaum P, Kaczorowski GJ, et al. Purification and characterization of a unique, potent, peptidyl probe for the high conductance calciumactivated potassium channel from venom of the scorpion Buthus tamulus. J Biol Chem. 1990; 265: 11083-11090. PMID: 1694175

25. Garcia ML, Gao Y, McManus OB, Kaczorowski GJ. Potassium channels: from scorpion venoms to high-resolution structure. Toxicon. 2001; 39: 739-748. PMID: 11137531

26. Joiner WJ, Tang MD, Wang LY, Dworetzky SI, Boissard CG, Gan L, et al. Formation of intermediateconductance calcium-activated potassium channels by interaction of Slack and Slo subunits. Nat Neurosci. 1998; 1: 462-469. PMID: 10196543

27. Yuan A, Santi CM, Wei A, Wang ZW, Pollak K, Nonet M, et al. The sodium-activated potassium channel is encoded by a member of the Slo gene family. Neuron. 2003; 37: 765-773. PMID: 12628167

28. Bhattacharjee A, Joiner WJ, Wu M, Yang Y, Sigworth FJ, Kaczmarek LK. Slick (Slo2.1), a rapidly-gating sodium-activated potassium channel inhibited by ATP. J Neurosci. 2003; 23: 11681-11691. PMID: 14684870

29. Dryer $\mathrm{SE} . \mathrm{Na}^{+}$-activated $\mathrm{K}^{+}$channels: a new family of large-conductance ion channels. Trends Neurosci. 1994; 17: 155-160. PMID: 7517595

30. Kim YC, Sim JH, Kang TM, Suzuki H, Kim SR, Kwon SC, et al. Sodium-activated potassium current in guinea pig gastric myocytes. J Korean Med Sci. 2007; 22: 57-62. PMID: 17297252

31. Ashcroft FM. ATP-sensitive potassium channelopathies: focus on insulin secretion. J Clin Invest; 2005; 115: 2047-2058. PMID: 16075046

32. Ashcroft FM, Gribble FM. Tissue-specific effects of sulfonylureas: lessons from studies of cloned K (ATP) channels. J Diabetes Complications. 2000; 14: 192-196. PMID: 11004427

33. Mayorga-Wark O, Dubinsky WP, Schultz SG. Reversal of glibenclamide and voltage block of an epithelial KATP channel. Am J Physiol. 1996; 271: 1122-1130.

34. Ashcroft SJ, Ashcroft FM. Properties and functions of ATP-sensitive K-channels. Cell Signal. 1990; 2: 197-214. PMID: 2119205

35. Benz I, Kohlhardt M. Distinct modes of blockade in cardiac ATP-sensitive K+ channels suggest multiple targets for inhibitory drug molecules. J Membr Biol. 1994; 142: 309-322. PMID: 7707360

36. Edwards G, Weston AH. The pharmacology of ATP-sensitive potassium channels. Annu Rev Pharmacol Toxicol. 1993; 33: 597-637. PMID: 8494353

37. Brady PA, Alekseev AE, Aleksandrova LA, Gomez LA, Terzic A. A disrupter of actin microfilaments impairs sulfonylurea-inhibitory gating of cardiac K KTP channels. Am J Physiol. 1996; 271: 2710-2716. 
38. Varadi A, Grant A, McCormack M, Nicolson T, Magistri M, Mitchell KJ, et al. Intracellular ATP-sensitive $\mathrm{K}^{+}$channels in mouse pancreatic beta cells: against a role in organelle cation homeostasis. Diabetologia. 2006; 49: 1567-1577. PMID: 16752175

39. Zhou M, Tanaka O, Sekiguchi M, He HJ, Yasuoka Y, Itoh H, et al. ATP-sensitive K+-channel subunits on the mitochondria and endoplasmic reticulum of rat cardiomyocytes. J Histochem Cytochem. 2005; 53: 1491-1500. PMID: 15983113

40. Gribble FM, Tucker SJ, Seino S, Ashcroft FM. Tissue specificity of sulfonylureas: studies on cloned cardiac and beta-cell K(ATP) channels. Diabetes. 1998; 47: 1412-1418. PMID: 9726229

41. Nagashima K, Takahashi A, Ikeda H, Hamasaki A, Kuwamura N, Yamada Y, et al. Sulfonylurea and non-sulfonylurea hypoglycemic agents: pharmacological properties and tissue selectivity. Diabetes Res Clin Pract. 2004; 66: 75-78.

42. Inagaki N, Gonoi T, Clement JP, Wang CZ, Aguilar-Bryan L, Bryan J, et al. A family of sulfonylurea receptors determines the pharmacological properties of ATP-sensitive $\mathrm{K}^{+}$channels. Neuron. 1996; 16 : 1011-1017. PMID: 8630239

43. Grell W, Hurnaus R, Griss G, Sauter R, Rupprecht E, Mark M, et al. Repaglinide and related hypoglycemic benzoic acid derivatives. J Med Chem. 1998; 41: 5219-5246. PMID: 9857091

44. Malaisse WJ. Insulinotropic action of meglitinide analogues: modulation by an activator of ATPsensitive $\mathrm{K}^{+}$channels and high extracellular K+ concentrations. Pharmacol Res. 1995; 32: 111-114. PMID: 8745339

45. Kuniyasu A, Kaneko K, Kawahara K, Nakayama H. Molecular assembly and subcellular distribution of ATP-sensitive potassium channel proteins in rat hearts. FEBS Lett. 2003; 552: 259-263. PMID: 14527696

46. Wheeler A, Wang C, Yang K, Fang K, Davis K, Styer AM, et al. Coassembly of different sulfonylurea receptor subtypes extends the phenotypic diversity of ATP-sensitive potassium $\left(\mathrm{K}_{\mathrm{ATP}}\right)$ channels. Mol Pharmacol. 2008; 74: 1333-1344. doi: 10.1124/mol.108.048355 PMID: 18723823

47. Siemen D, Loupatatzis C, Borecky J, Gulbins E, Lang F. Ca2+-activated K channel of the BK-type in the inner mitochondrial membrane of a human glioma cell line. Biochem Biophys Res Commun. 1999 257: 549-554. PMID: 10198249

48. Maruyama $\mathrm{Y}$, Shimada $\mathrm{H}$, Taniguchi $\mathrm{J}$. Ca2+-activated $\mathrm{K}+$-channels in the nuclear envelope isolated from single pancreatic acinar cells. Pflugers Arch. 1995; 430: 148-150. PMID: 7667076

49. Decrouy A, Juteau M, Proteau S, Teijiera J, Rousseau E. Biochemical regulation of sarcoplasmic reticulum $\mathrm{Cl}^{-}$channel from human atrial myocytes: involvement of phospholamban. J Mol Cell Cardiol. 1996; 28: 767-780. PMID: 8732504

50. Picher M, Decrouy A, Proteau S, Rousseau E. Conducting and voltage-dependent behaviors of the native and purified SR Ca2+-release channels from the canine diaphragm. Biochim Biophys Acta. 1997; 1328: 243-260. PMID: 9315621

51. Dolai S, Pal S, Yadav RK, Adak S. Endoplasmic reticulum stress-induced apoptosis in Leishmania through Ca2+-dependent and caspase-independent mechanism. J Biol Chem. 2011; 286: 13638-13646. doi: 10.1074/jbc.M110.201889 PMID: 21330370

52. Wegierski T, Steffl D, Kopp C, Tauber R, Buchholz B, Nitschke R, et al. TRPP2 channels regulate apoptosis through the $\mathrm{Ca}^{2+}$ concentration in the endoplasmic reticulum. EMBO J. 2009; 28: 490-499. doi: 10.1038/emboj.2008.307 PMID: 19153608 